Article

\title{
Batch Test Screening of Industrial Product/Byproduct Filter Materials for Agricultural Drainage Water Treatment
}

\author{
Barry J. Allred \\ U.S. Department of Agriculture, Agricultural Research Service, Soil Drainage Research Unit, 590 Woody Hayes \\ Drive, Columbus, OH 43210, USA; Barry.Allred@ars.usda.gov; Tel.: +1-614-292-4459
}

Received: 31 August 2017; Accepted: 10 October 2017; Published: 14 October 2017

\begin{abstract}
Filter treatment may be a viable means for removing the nitrate $\left(\mathrm{NO}_{3}{ }^{-}\right)$, phosphate $\left(\mathrm{PO}_{4}{ }^{3-}\right)$, and pesticides discharged with agricultural drainage waters that cause adverse environmental impacts within the U.S. on local, regional, and national scales. Laboratory batch test screening for agricultural drainage water treatment potential was conducted on 58 industrial product/byproduct filter materials grouped into six categories: (1) high carbon content media; (2) high iron content media; (3) high aluminum content media; (4) surfactant modified clay/zeolite; (5) coal combustion residuals; and (6) spent foundry sands. Based on a percent contaminant removal criteria of $75 \%$ or greater, seven industrial products/byproducts were found to meet this standard for $\mathrm{NO}_{3}{ }^{-}$alone, 44 met this standard for $\mathrm{PO}_{4}{ }^{3-}$, and 25 met this standard for the chlorinated triazine herbicide, atrazine. Using a $50 \%$ or greater contaminant removal criteria, five of the industrial product/byproduct filter materials exhibited potential for removing $\mathrm{NO}_{3}{ }^{-}, \mathrm{PO}_{4}{ }^{3-}$, and atrazine together; eight showed capability for combined $\mathrm{NO}_{3}{ }^{-}$and $\mathrm{PO}_{4}{ }^{3-}$ removal; 21 showed capability for combined $\mathrm{PO}_{4}{ }^{3-}$ and atrazine removal; and nine showed capability for combined $\mathrm{NO}_{3}{ }^{-}$and atrazine removal. The results of this study delineated some potential industrial product/byproduct filter materials for drainage water treatment; however, a complete feasibility evaluation for drainage water treatment of any of these filter materials will require much more extensive testing.
\end{abstract}

Keywords: agricultural drainage water treatment; industrial product/byproduct filter materials; batch test screening; nitrate; phosphate; atrazine

\section{Introduction}

In humid regions, such as the Midwest U.S., agricultural drainage practices commonly employ buried pipe networks to remove excess soil moisture by lowering the shallow water table, which in turn improves crop yields. Subsurface drainage is also utilized in semiarid to arid regions to prevent soil salinity build-up in farm fields. Agricultural fertilizer and pesticide applications, combined with subsurface drainage practices, often produce adverse water quality impacts within the U.S. on local, regional, and national scales [1-5].

Nitrate $\left(\mathrm{NO}_{3}{ }^{-}\right)$is a major environmental concern with respect to subsurface drainage. Research conducted in the Midwest U.S. and Canada indicates that the nitrate-nitrogen $\left(\mathrm{NO}_{3}{ }^{-}-\mathrm{N}\right)$ concentration in waters discharged from agricultural subsurface drainage systems typically range from 0 to 50 $\mathrm{mg} / \mathrm{L}$, although higher values are fairly common [6-8]. Phosphate $\left(\mathrm{PO}_{4}{ }^{3-}\right.$, also referred to as orthophosphate, dissolved phosphorous, or soluble reactive phosphorous) is another nutrient typically found in subsurface drainage waters. A review of previous investigations indicate that subsurface drainage phosphate- $\mathrm{P}\left(\mathrm{PO}_{4}{ }^{3-}-\mathrm{P}\right)$ values in agricultural settings are typically below $0.25 \mathrm{ppm}$, and, in fact, most often $0.1 \mathrm{ppm}$ or less; however, values as high and even exceeding $1.0 \mathrm{ppm}$ have been reported [9-14]. Pesticides are likewise frequently present in agricultural drainage water [11,15], and 
atrazine, a chlorinated triazine herbicide, used extensively for corn and sorghum production in the U.S. and Canada, happens to be one of the most common. Atrazine is usually found in subsurface drainage waters at relatively low concentrations, normally well less than $0.1 \mathrm{mg} / \mathrm{L}$ [16-18], although Gaynor et al. [19] did measure a maximum subsurface drainage water atrazine concentration of $0.35 \mathrm{mg} / \mathrm{L}$ in research conducted on small test plots. A typical agricultural subsurface drainage system is comprised of drainage pipe laterals that connect to a main collector pipe that outlets into a ditch or small stream. Consequently, an in-line filter treatment system located on the main collector pipe near the subsurface drainage system outlet could be a viable means for removing oxyanion nutrients $\left(\mathrm{NO}_{3}{ }^{-}\right.$and $\left.\mathrm{PO}_{4}{ }^{3-}\right)$ and pesticides from drainage waters before these waters are discharged into the environment. However, choosing the appropriate porous, permeable, chemically reactive material that is incorporated into a filter system to remove nutrients and/or pesticides will be critical for obtaining effective and efficient agricultural drainage water treatment.

One possible mechanism by which various filter materials could remove $\mathrm{NO}_{3}{ }^{-}$is anion adsorption due to electrostatic attraction between negatively charged $\mathrm{NO}_{3}{ }^{-}$ions and positively charged surfaces of filter material particles [20,21]. Filter materials might also remove $\mathrm{NO}_{3}{ }^{-}$via oxidation/reduction reactions that convert $\mathrm{NO}_{3}{ }^{-}$to ammonia/ammonium, $\mathrm{NH}_{3} / \mathrm{NH}_{4}{ }^{+}$, or nitrogen gas, $\mathrm{N}_{2}$ [22-26] . Compounds containing $\mathrm{NO}_{3}{ }^{-}$tend to be extremely soluble in water [27], and, consequently, chemical precipitation is an unlikely $\mathrm{NO}_{3}{ }^{-}$removal mechanism. Nevertheless, cations (e.g., $\mathrm{Al}^{3+}, \mathrm{Ca}^{2+}, \mathrm{Fe}^{3+}$, $\mathrm{Mg}^{2+}$, etc.) dissolved from filter materials can combine with $\mathrm{PO}_{4}{ }^{3-}$ to form low solubility chemical precipitates [28-31]. Direct $\mathrm{PO}_{4}{ }^{3-}$ adsorption typically involves ligand exchange at oxygen containing functional group sites present along surfaces of filter material particles [29-33]. Phosphate adsorption can also occur due to electrostatic attraction between negatively charged $\mathrm{PO}_{4}{ }^{3-}$ ions and positively charged filter material surfaces [34-36]. The chlorinated triazine herbicide, atrazine, can be classified as an organochloride pesticide, and organochloride pesticides, such as atrazine, can be removed by filter materials through London-van der Waals dispersion forces, hydrophobic interactions, and reductive dechlorination [37-40].

A large number of industrial products/byproducts could have potential as filter materials utilized for removing oxyanion nutrients (i.e., $\mathrm{NO}_{3}{ }^{-}$and $\mathrm{PO}_{4}{ }^{3-}$ ) and/or organochloride pesticides (e.g., atrazine, alchlor, metolachlor, 2,4-D, etc.) from agricultural drainage waters. Simple batch tests can be employed for an initial determination as to whether a particular industrial product/byproduct filter material has some capability for drainage water treatment. As such, these tests can prove very useful for preliminary screening purposes by clearly indicating which industrial products/byproducts do not remove $\mathrm{NO}_{3}{ }^{-}, \mathrm{PO}_{4}{ }^{3-}$, and/or organochloride pesticides and are accordingly not appropriate filter materials for drainage water treatment. Obviously, for those filter materials that do pass this batch test screening process, more extensive evaluation is certainly needed (hydraulic conductivity measurements, adsorption isotherm experiments, long duration column tests, etc.) in order to completely determine overall viability for use in treating nutrients and pesticides present in drainage waters. Consequently, the stated goal of this research project was to carry out batch test screening of 58 industrial products/byproducts to find ones exhibiting some capacity for removing $\mathrm{NO}_{3}{ }^{-}, \mathrm{PO}_{4}{ }^{3-}$, and/or atrazine, thereby delineating those warranting further investigation as possible drainage water treatment filter materials.

\section{Materials and Methods}

\subsection{Industrial Product/Byproduct Filter Materials}

The industrial products/byproducts screened as potential drainage water treatment filter materials in this study can be grouped into six categories: (1) high carbon content media-14 in total; (2) high iron content media-17 in total; (3) high aluminum content media-6 in total; (4) surfactant modified clay/zeolite -6 in total; (5) coal combustion residuals- 8 in total; and (6) spent foundry sands -7 in total. These six categories of filter materials were chosen on the basis of 
past research indicating capability for removing oxyanion and/or organic contaminants from wastewaters [24,38,41-45]. For consistency, so that all filter materials passed a No. 10 sieve (2 mm), some of the industrial product/byproducts were broken up into smaller granules using a ceramic mortar and pestle. The only filter materials requiring more extensive preparation were the surfactant modified clay or zeolite, which were generated by mixing $100 \mathrm{~g}$ of surfactant, $250 \mathrm{~g}$ of clay or zeolite, and $500 \mathrm{~g}$ of ultrapure deionized water, allowing $24 \mathrm{~h}$ for the mixture to equilibrate, and then afterwards draining excess liquid from the surfactant coated clay or zeolite particles. The 58 industrial product/byproducts tested are listed by category as follows and include: (1) the designated short notation for the material used throughout the rest of the article; (2) a descriptive name of the material; (3) organization and/or facility source of the material; and, if applicable, (4) material marketing/research number. The industrial product/byproduct lists are formatted in the following manner:

FILTER MATERIAL NOTATION: Filter Material Description (Filter Material Source), Marketing/Research Number.

\section{High Carbon Content Media}

COAL1: Lignite (American Coal Foundation, Washington, DC, USA).

COAL2: Bituminous Coal (American Coal Foundation, Washington, DC, USA).

COAL3: Sub-Bituminous Coal-Wyodak-Anderson Mine, Wyoming, USA (Argonne National Laboratory, Lemont, IL, USA).

COAL4: Bituminous Coal-Illinois \#6 Mine, Illinois, USA (Argonne National Laboratory, Lemont, IL, USA).

COAL5: Bituminous Coal-Bailey Enlow Fork Mine, Pennsylvania, USA (CONSOL Energy Inc., Canonsburg, PA, USA).

COAL6: Bituminous Coal_Emery Mine, Utah, USA (Consol Energy, Canonsburg, PA, USA).

COKE1: Metallurgical Coke (Mid-Continent Coal and Coke Company, Cleveland, OH, USA).

COKE2: Petroleum Coke (Oxbow Carbon LLC, West Palm Beach, FL, USA).

CHAR: Charcoal (Wicked Good Charcoal, Inc., Kennebunk, ME, USA).

AC1: Steam Activated Carbon (Alfa Aesar, Ward Hill, MA, USA).

AC2: Coconut Shell Based Granular Steam Activated Carbon (PICA USA, Inc., Columbus, OH, USA), G55-C(6) $12 \times 30$.

AC3: Hardwood Based Chemically Activated Carbon (PICA USA, Inc., Columbus, OH, USA), GX191 12x40.

AC4: Coal Based Granular Steam Activated Carbon (PICA USA, Inc., Columbus, OH, USA), HYDRO F22 12x40.

AC5: Hardwood Based Powdered Steam Activated Carbon (PICA USA, Inc., Columbus, OH, USA), HYDRO MP23.

\section{High Iron Content Media}

ZVI1: Iron Aggregate (Connelly-GPM, Inc., Chicago, IL, USA), CC-1190.

ZVI2: Iron Aggregate (Connelly-GPM, Inc., Chicago, IL, USA), CC-1004.

ZVI3: Carbon Reduced Zero Valent Iron (Hepure Technologies, Inc., Flemington, NJ, USA), H-200.

ZVI4: Hydrogen Reduced Zero Valent Iron (North American Höganäs, Inc., Hollsopple, PA, USA), R-12.

SMI1: Sulfur Modified Iron (North American Höganäs, Inc., Hollsopple, PA, USA), \#5014.

SMI2: Sulfur Modified Iron (North American Höganäs, Inc., Hollsopple, PA, USA), R12S6.

SMI3: Sulfur Modified Iron (North American Höganäs, Inc., Hollsopple, PA, USA), W40S6.

PIC: Porous Iron Composite (North American Höganäs, Inc., Hollsopple, PA, USA).

IS1: Pyrite-Natural (FeS 2 ) (Alfa Aesar, Ward Hill, MA, USA).

IS2: Iron Sulfide (FeS) (Alfa Aesar, Ward Hill, MA, USA).

IS3: Pyrrhotite-Natural (Fe ${ }_{(1-x)} S$ with $x=0$ to 0.2$)$ (Ward's Science, Rochester, NY, USA). 
IO1: Granular Ferric Oxide (FeOOH) (Severn Trent-North America, Horsham, PA, USA), E33.

IO2: Black Ion Oxide (Severn Trent-North America, Horsham, PA, USA), E33 HC-F.

IO3: Geothite-Natural (FeOOH) (Ward's Science, Rochester, NY, USA).

IO4: Hematite-Natural ( $\mathrm{Fe}_{2} \mathrm{O}_{3}$ ) (Ward's Science, Rochester, NY, USA).

IO5: Ferrihydrite Sludge $\left(\mathrm{Fe}_{2} \mathrm{O}_{3} \cdot \mathbf{0 . 5} \mathrm{H}_{2} \mathrm{O}\right)$ (Water Treatment Plant in Memphis, TN, USA.

IO6: Iron Oxyhydroxide (Amorphous FeOOH and Ferrihydrite) (Mach I, Inc., King of Prussia, PA, USA), NANOCAT ${ }^{\circledR}$ SFIO.

\section{High Aluminum Content Media}

A01: Bauxite (Ward's Science, Rochester, New York, USA).

AO2: Aluminum Hydroxide ( $\mathrm{Al}(\mathrm{OH})_{3}$ ) (Alfa Aesar, Ward Hill, MA, USA).

AO3: Synthetic Gibbsite $\left(\mathrm{Al}(\mathrm{OH})_{3}\right)$ (Ward's Science, Rochester, NY, USA).

AO4: Aluminum Oxide $\left(\mathrm{Al}_{2} \mathrm{O}_{3}\right)$ (Alfa Aesar, Ward Hill, MA, USA).

AO5: Aluminum Oxide-Alpha $\left(\mathrm{Al}_{2} \mathrm{O}_{3}\right)$ (Alfa Aesar, Ward Hill, MA, USA).

AO6: Aluminum Oxide—Gamma $\left(\mathrm{Al}_{2} \mathrm{O}_{3}\right)$ (Alfa Aesar, Ward Hill, MA, USA).

\section{Surfactant Modified Clay/Zeolite}

SMC1: Surfactant Modified Clay-(1-Hexadecyl)trimethylammonium Bromide (Alfa Aesar, Ward Hill, MA, USA) + Sodium Montmorillonite (The Clay Minerals Society, Chantilly, VA, USA), SWy-2.

SMC2: Surfactant Modified Clay-Alkyldimethylnaphthyl Ammonium Chloride (Mason Chemical Company, Arlington Heights, IL, USA), Maquat NKC-50 I + Sodium Montmorillonite (The Clay Minerals Society, Chantilly, VA, USA), SWy-2.

SMC3: Surfactant Modified Clay-Cocoalkylmethyl PEG-15 Ammonium Chloride (Mason Chemical Company, Arlington Heights, IL, USA), Maquat C-15 + Sodium Montmorillonite (The Clay Minerals Society, Chantilly, VA, USA), SWy-2.

SMZ1: Surfactant Modified Zeolite-(1-Hexadecyl)trimethylammonium Bromide (Alfa Aesar, Ward Hill, MA, USA) + Clinoptilolite (Z-Olite Inc., Logan, UT, USA).

SMZ2: Surfactant Modified Zeolite-Alkyldimethylnaphthyl Ammonium Chloride (Mason Chemical Company, Arlington Heights, Illinois, USA), Maquat NKC-50 I + Clinoptilolite (Z-Olite Inc., Logan, UT, USA).

SMZ3: Surfactant Modified Zeolite-Cocoalkylmethyl PEG-15 Ammonium Chloride (Mason Chemical Company, Arlington Heights, IL, USA), Maquat C-15 + Clinoptilolite (Z-Olite Inc., Logan, UT, USA).

\section{Coal Combustion Residuals}

CCR1: Fly Ash-Gavin Power Plant, Ohio, USA (American Electric Power, Columbus, OH, USA).

CCR2: Bottom Ash-Gavin Power Plant, Ohio, USA (American Electric Power, Columbus, OH, USA). CCR3: FGD Material (Scrubber Sludge)—Gavin Power Plant, Ohio, USA (American Electric Power, Columbus, OH, USA).

CCR4: Gypsum Quality FGD Material-Gavin Power Plant, Ohio, USA (American Electric Power, Columbus, OH, USA).

CCR5: Fly Ash-Conesville Power Plant, Ohio, USA (American Electric Power, Columbus, OH, USA). CCR6: Fly Ash-Mitchell Power Plant, West Virginia, USA (American Electric Power, Columbus, $\mathrm{OH}, \mathrm{USA})$.

CCR7: Fly Ash-W. C. Beckjord Power Plant, Ohio, USA (Duke Energy, Charlotte, NC, USA).

CCP8: Calciment Fly Ash (Mitek Resources, Beavercreek, OH, USA).

\section{Spent Foundry Sands}

FS1: Green Sand-Steel Casting Foundry (Columbus Steel Castings Company, Columbus, OH, USA). FS2: No Bake Sand-Steel Casting Foundry (Fisher Cast Steel, Inc., West Jefferson, OH, USA). 
FS3: Green Sand-Aluminum Casting Foundry (Industrial Aluminum and Bronze Foundry, Columbus, $\mathrm{OH}, \mathrm{USA})$.

FS4: Green Sand-Iron Casting Foundry_Vine Street Facility, Kenton, Ohio, USA (Kenton Iron Products, Kenton, OH, USA).

FS5: No Bake Sand_Iron Casting Foundry_Vision Drive Facility, Kenton, Ohio, USA (Kenton Iron Products, Kenton, OH, USA).

FS6: No Bake Sand-Iron Casting Foundry (Liberty Casting Company, Delaware, OH, USA).

FS7: Green Sand-Iron Casting Foundry (General Motors Powertrain Defiance Foundry, Defiance, $\mathrm{OH}, \mathrm{USA})$.

\subsection{Nitrate/Phosphate/Atrazine Test Solution}

Potential industrial product/byproduct filter materials were screened using a test solution that, by drainage water standards, had relatively high concentrations of nitrate $\left(\mathrm{NO}_{3}{ }^{-}\right)$, phosphate $\left(\mathrm{PO}_{4}{ }^{3-}\right)$, and the organochloride pesticide, atrazine. This test solution contained $50 \mathrm{ppm}$ nitrate-nitrogen $\left(\mathrm{NO}_{3}{ }^{-}-\mathrm{N}\right), 0.25 \mathrm{ppm}$ phosphate-phosphorous $\left(\mathrm{PO}_{4}{ }^{3-}-\mathrm{P}\right)$, and $0.4 \mathrm{ppm}$ atrazine. Nitrate was added as potassium nitrate $\left(\mathrm{KNO}_{3}-360 \mathrm{ppm}\right)$, and $\mathrm{PO}_{4}{ }^{3-}$ was added as dibasic sodium phosphate $\left(\mathrm{Na}_{2} \mathrm{HPO}_{4}-1.15 \mathrm{ppm}\right)$. Using a test solution with $\mathrm{NO}_{3}{ }^{-}, \mathrm{PO}_{4}{ }^{3-}$, and atrazine concentrations that were relatively high by drainage water standards ensured a more rigorous evaluation as to whether specific industrial product/byproduct filter materials exhibited promise for drainage water treatment.

Furthermore, $565 \mathrm{mg} / \mathrm{L}$ calcium sulfate $\left(\mathrm{CaSO}_{4}\right)$ and $140 \mathrm{mg} / \mathrm{L}$ potassium chloride $(\mathrm{KCl})$ were also added so that inorganic anions/cations $\left(\mathrm{SO}_{4}{ }^{2-}, \mathrm{Cl}^{-}, \mathrm{Ca}^{2+}\right.$, and $\left.\mathrm{K}^{+}\right)$normally found in drainage water were also included in the test solution. The dissolution of $\mathrm{Na}_{2} \mathrm{HPO}_{4}$ added a small amount of sodium $\left(\mathrm{Na}^{+}\right)$, another cation commonly found in drainage waters. Electrical conductivity (EC) is used to gauge the solution salinity, and, hence, the amount of dissolved anions/cations present. The EC of the batch test solution was $1.38 \mathrm{dS} / \mathrm{m}$. Based on unreported drainage water EC measurements in northwest Ohio $\left(\mathrm{EC}_{\mathrm{AVG}}-0.31 \mathrm{dS} / \mathrm{m}\right)$ and central Ohio $\left(\mathrm{EC}_{\mathrm{AVG}}-0.70 \mathrm{dS} / \mathrm{m}\right)$, the test solution $\mathrm{EC}$ probably represents the upper range of EC values likely found for subsurface drainage under Midwest U.S. conditions. However, agricultural subsurface drainage EC values can be substantially larger in locations with arid or semi-arid climates. Subsurface drainage discharge EC values of $32 \mathrm{dS} / \mathrm{m}$ have been reported for the Murrumbidgee Irrigation Area, of New South Wales, Australia [46], and subsurface drainage EC values as high as $8 \mathrm{dS} / \mathrm{m}$ (converted from total dissolved solid concentrations) have been measured at the Broadview Water District in the San Joaquin Valley, California [47]. Based on the most commonly employed salinity classification scale for water extracted from a saturated soil paste $[48,49]$, the solution used for the batch tests in this study would be classified as non-saline ( 0 to $2 \mathrm{dS} / \mathrm{m}$ ). Consequently, the total amounts of dissolved anions and cations present in the test solution is not unrealistic considering the wide range of EC measured salinity found around the world for subsurface drainage waters.

\subsection{Batch Test Screening Procedures}

As previously stated, the overall goal of this laboratory investigation was to evaluate whether specific industrial product/byproduct filter materials exhibited promise with respect to agricultural drainage water treatment. This goal was accomplished by conducting batch test screening to measure the percent $\mathrm{NO}_{3}{ }^{-}, \mathrm{PO}_{4}{ }^{3-}$, and atrazine removal by various filter materials. In each filter material batch test, 1 to $5 \mathrm{~g}$ ( $5 \mathrm{~g}$ predominately) of filter material and 38 to $40 \mathrm{~g}$ of test solution ( $40 \mathrm{~g}$ predominantly) were combined in a $50 \mathrm{~mL}$ Teflon FEP (fluorinated ethylene propylene) centrifuge tube. Less than $5 \mathrm{~g}$ of filter material and/or $40 \mathrm{~g}$ of test solution were used in some batch tests in order to accommodate the limited $50 \mathrm{~mL}$ volume of the centrifuge tubes. The predominant filter material to solution ratio (1:8 by weight) employed for this investigation was chosen based on the filter material to solution ratios used in previous batch test studies [50-53]. The filter material and solution were thoroughly mixed by placing the centrifuge tube containing filter material and solution on a laboratory rotator (Mini 
LabRoller Rotator, Labnet International, Inc., Woodbridge, NJ, USA) operated at $20 \mathrm{rpm}$ (Figure 1). Each batch was then stopped after $24 \mathrm{~h}$ of mixing. A $24 \mathrm{~h}$ mixing period was employed so as to allow ample time for chemical reactions to occur by which $\mathrm{NO}_{3}{ }^{-}, \mathrm{PO}_{4}{ }^{3-}$, and atrazine could be removed by the industrial products/byproducts evaluated. Procedures for the control batch tests were the same except that only solution $(40 \mathrm{~g})$, but no filter material, was added to the Teflon centrifuge tube.

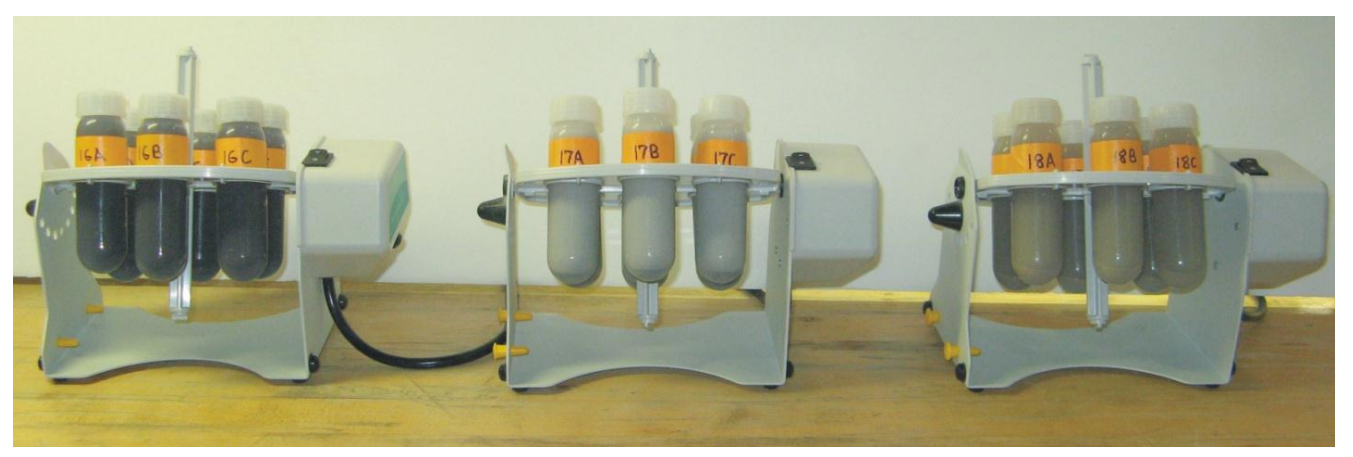

Figure 1. Filter material and test solution mixed in Teflon centrifuge tubes mounted on laboratory rotators.

Once these tests were completed, the Teflon centrifuge tubes containing filter material and solution were centrifuged at $2500 \mathrm{rpm}(800 \mathrm{~g}$ ) for $10 \mathrm{~min}$ in order to separate the filter material from the solution. Part of the solution, set aside for analysis of atrazine, was decanted into a $15 \mathrm{~mL}$ glass centrifuge tube and centrifuged at $2500 \mathrm{rpm}(800 \mathrm{~g})$ for an additional $60 \mathrm{~min}$, then decanted once more into a second $15 \mathrm{~mL}$ glass centrifuge tube to ensure that all filter material had been removed from contact with the solution. The remaining solution in the original Teflon centrifuge tube was used for analysis of $\mathrm{NO}_{3}{ }^{-}$and $\mathrm{PO}_{4}{ }^{3-}$. This remaining solution was itself decanted into a $50 \mathrm{~mL}$ polypropylene centrifuge tube and centrifuged at $2500 \mathrm{rpm}(800 \mathrm{~g})$ for an additional $60 \mathrm{~min}$, then decanted once more into a $40 \mathrm{~mL}$ glass vial, again to ensure that filter material had been removed from contact with solution. The rather rigorous process of separating the solution from the filter material was done for the purpose of discontinuing chemical reactions between the filter material and test solution after the batch test had completed. For consistency purposes, the same solution separation procedures were employed after completion of the control batch tests, even though these batch tests were conducted with solution only and no filter material.

Solution $\mathrm{pH}$ was measured at batch test completion using a Hanna Instruments (Woonsocket, RI, USA) Checker $\mathrm{pH}$ meter. Nitrate-nitrogen was determined colorimetrically by a copperized-cadmium reduction method [54] using a Lachat Instruments (Milwaukee, WI, USA), QuikChem 8000 Flow Injection Analysis System. Phosphate-phosphorous was determined colorimetrically by an ascorbic acid reduction method [54] also using the Lachat Instruments, QuikChem 8000 Flow Injection Analysis System. Two different methods were employed to measure the atrazine present in solution at batch test completion. Immunoassay [55] was one of the atrazine analysis methods, and for this method, a Strategic Diagnostic Inc. (Newark, NJ, USA), RaPID Assay Atrazine Test Kit and RPA-I Analyzer (spectrophotometer) were utilized. The U.S. Environmental Protection Agency Method 525.2, based on gas chromatography-mass spectrometry (GC-MS), was the second atrazine analysis method [56]. The GC-MS atrazine analysis done for this study used a Varian, Inc. (Palo Alto, CA, USA), Saturn 2200 Ion Trap GC/MS System.

A small number of solution samples from the filter material screening batch tests were submitted for atrazine analysis to an accredited/certified outside laboratory (Soil, Water, and Agricultural Testing Laboratory, New Mexico State University, Las Cruces, New Mexico) for the purpose of evaluating the atrazine analysis accuracy of the immunoassay and GC-MS methods that were used in-house. The outside laboratory atrazine analysis (GC-MS methods) indicated that the in-house immunoassay atrazine analysis tended to somewhat underestimate the amount of filter material induced atrazine removal (higher measured values for atrazine concentration), while the in-house GC-MS atrazine 
analysis tended to somewhat overestimate the amount of filter material induced atrazine removal (lower measured values for atrazine concentration). Therefore, to avoid bias, results are reported for both the in-house immunoassay atrazine analysis and the in-house GC-MS atrazine analysis. Batch tests for screening porous iron composite (PIC) and spent foundry sands were analyzed for atrazine with just the immunoassay method due to repairs being carried out at the time on the Varian, Inc., Saturn 2200 Ion Trap GC/MS System.

Six batch test replicates were carried for each filter material, while, for control tests (no filter material present), there were seven replicates. Solution concentrations of $\mathrm{NO}_{3}{ }^{-}, \mathrm{PO}_{4}{ }^{3-}$, and atrazine were measured for each of the six replicates corresponding to a particular filter material and also for the seven control test replicates. The known solution concentrations at the beginning of the batch tests and the measured solution concentrations at batch test completion were used to calculate percent $\mathrm{NO}_{3}{ }^{-}, \mathrm{PO}_{4}{ }^{3-}$, and atrazine removal with the following equation.

$$
\% \text { Removal }=\frac{(\text { Solution Concentration at Start of Test-Solution Concentration at End of Test })}{\text { Solution Concentration at Start of Test }} \times 100
$$

Solution $\mathrm{pH}$ was also measured for all batch test replicates, with the exception of PIC and the spent foundry sands. Due to a miscommunication regarding procedures, the $\mathrm{pH}$ for PIC was measured on just three of the six replicates, while the $\mathrm{pH}$ for the spent foundry sands were measured on only one replicate.

\section{Results and Discussion}

Results for the batch test screening of 58 industrial products/byproducts are provided in Table 1 (high carbon content media), Table 2 (high iron content media), Table 3 (high aluminum content media), Table 4 (surfactant modified clay/zeolite), Table 5 (coal combustion residuals), and Table 6 (spent foundry sands). These tables report the amounts of filter material and test solution used, $\mathrm{pH}$ of solution at batch test completion, along with the average (and standard deviation) of the percent nitrate $\left(\mathrm{NO}_{3}{ }^{-}\right)$, phosphate $\left(\mathrm{PO}_{4}{ }^{3-}\right)$, and atrazine removal. For reference, nitrate-nitrogen $\left(\mathrm{NO}_{3}{ }^{-}-\mathrm{N}\right)$, phosphate-phosphorous $\left(\mathrm{PO}_{4}{ }^{3-}-\mathrm{P}\right)$, and atrazine removal calculated as mg of contaminant per $\mathrm{g}$ of filter material is provided in the Appendix A Tables A1-A6. The standard deviation of percent $\mathrm{NO}_{3}{ }^{-}$, $\mathrm{PO}_{4}{ }^{3-}$, and atrazine removal was in general relatively small compared to the corresponding percent $\mathrm{NO}_{3}{ }^{-}, \mathrm{PO}_{4}{ }^{3-}$, and atrazine removal average, which shows that for a particular filter material there was usually good consistency in contaminant removal results between replicate batch tests.

Table 1. Batch test screening results for high carbon content media.

\begin{tabular}{|c|c|c|c|c|c|c|c|}
\hline $\begin{array}{l}\text { Industrial } \\
\text { Product/ } \\
\text { Byproduct }\end{array}$ & $\begin{array}{c}\text { Dry (Wet) } \\
\text { Filter } \\
\text { Material } \\
\text { Amount (g) }\end{array}$ & $\begin{array}{c}\text { Test } \\
\text { Solution } \\
\text { Amount (g) }\end{array}$ & $\begin{array}{c}\text { Avg. } \\
\text { pH }\end{array}$ & $\begin{array}{l}\text { Nitrate-N } \\
\text { Average of } \\
\text { Percent } \\
\text { Removal and } \\
\text { (Std. Dev.) }\end{array}$ & $\begin{array}{l}\text { Phosphate-P } \\
\text { Average of } \\
\text { Percent } \\
\text { Removal and } \\
\text { (Std. Dev.) }\end{array}$ & $\begin{array}{c}\text { Atrazine } \\
\text { Immunoassay } \\
\text { Average of } \\
\text { Percent } \\
\text { Removal and } \\
\text { (Std. Dev.) }\end{array}$ & $\begin{array}{l}\text { Atrazine } \\
\text { GC-MS } \\
\text { Average of } \\
\text { Percent } \\
\text { Removal and } \\
\text { (Std. Dev.) }\end{array}$ \\
\hline COAL1 & 5.0 & 38.0 & 6.36 & $6.7(0.3)$ & $94.9(1.7)$ & $99.7(0.5)$ & $100.0(\sim 0.0)$ \\
\hline COAL4 & 5.0 & 39.5 & 7.79 & $3.3(0.7)$ & $96.5(3.1)$ & $100.0(\sim 0.0)$ & $100.0(\sim 0.0)$ \\
\hline COAL5 & 5.0 & 38.0 & 6.51 & $-1.8(0.4)$ & $98.1(2.9)$ & $98.4(0.9)$ & $95.7(0.6)$ \\
\hline COAL6 & 5.0 & 38.0 & 6.64 & $-1.2(1.6)$ & $52.6(6.0)$ & $90.8(0.9)$ & $94.5(0.6)$ \\
\hline COKE1 & 5.0 & 40.0 & 7.25 & $3.7(0.3)$ & $89.8(4.7)$ & $98.3(0.6)$ & $100.0(\sim 0.0)$ \\
\hline COKE2 & 5.0 & 39.0 & 7.16 & $4.0(0.1)$ & $2.3(1.5)$ & $72.5(2.8)$ & $87.0(1.8)$ \\
\hline CHAR & 5.0 & 38.0 & 8.42 & $-4.3(0.8)$ & $* * *$ & $99.3(0.7)$ & $100.0(\sim 0.0)$ \\
\hline AC4 & 5.0 & 40.0 & 7.81 & 80.4 (1.9) & $* * *$ & $100.0(\sim 0.0)$ & $100.0(\sim 0.0)$ \\
\hline AC5 & 2.5 & 39.0 & 11.91 & $9.1(0.3)$ & $95.2(1.9)$ & $99.8(0.5)$ & $100.0(\sim 0.0)$ \\
\hline
\end{tabular}

*** Signifies that substantially more phosphate-P was present in solution at the completion of the batch test than was present at the beginning of the batch test, thus indicating that the treatment material itself originally had significant quantities of readily released phosphate. 
Table 2. Batch test screening results for high iron content media.

\begin{tabular}{|c|c|c|c|c|c|c|c|}
\hline $\begin{array}{l}\text { Industrial } \\
\text { Product/ } \\
\text { Byproduct }\end{array}$ & $\begin{array}{c}\text { Dry (Wet) } \\
\text { Filter } \\
\text { Material } \\
\text { Amount (g) }\end{array}$ & $\begin{array}{c}\text { Test } \\
\text { Solution } \\
\text { Amount (g) }\end{array}$ & $\begin{array}{l}\text { Avg. } \\
\text { pH }\end{array}$ & $\begin{array}{l}\text { Nitrate-N } \\
\text { Average of } \\
\text { Percent } \\
\text { Removal and } \\
\text { (Std. Dev.) }\end{array}$ & $\begin{array}{l}\text { Phosphate-P } \\
\text { Average of } \\
\text { Percent } \\
\text { Removal and } \\
\text { (Std. Dev.) }\end{array}$ & $\begin{array}{l}\text { Atrazine } \\
\text { Immunoassay } \\
\text { Average of } \\
\text { Percent } \\
\text { Removal and } \\
\text { (Std. Dev.) }\end{array}$ & $\begin{array}{c}\text { Atrazine } \\
\text { GC-MS } \\
\text { Average of } \\
\text { Percent } \\
\text { Removal and } \\
\text { (Std. Dev.) }\end{array}$ \\
\hline ZVI1 & $4.9(5.0)$ & 40.0 & 9.21 & $9.8(1.1)$ & $95.7(4.3)$ & $87.6(2.6)$ & $91.1(0.6)$ \\
\hline ZVI2 & $4.8(5.0)$ & 40.0 & 9.58 & $6.0(0.5)$ & $99.2(0.7)$ & $95.2(1.7)$ & $95.8(0.1)$ \\
\hline ZVI3 & $4.3(5.0)$ & 40.0 & 9.54 & $-0.2(0.3)$ & $98.0(3.1)$ & $5.3(6.8)$ & $12.3(3.8)$ \\
\hline ZVI4 & $3.9(5.0)$ & 40.0 & 10.32 & $4.0(1.8)$ & 99.6 (1.9) & $-8.0(5.7)$ & $12.5(5.7)$ \\
\hline SMI1 & $4.3(5.0)$ & 40.0 & 9.68 & $63.2(2.5)$ & $98.9(0.4)$ & $16.4(3.3)$ & 30.2 (10.7) \\
\hline SMI2 & 5.0 & 40.0 & 9.12 & $75.3(3.0)$ & $96.0(0.4)$ & 26.8 (3.9) & $37.0(5.7)$ \\
\hline SMI3 & 5.0 & 40.0 & 3.09 & $98.6(0.3)$ & $94.0(0.7)$ & $61.8(5.8)$ & $82.5(2.1)$ \\
\hline PIC & 5.0 & 40.0 & $\begin{array}{c}10.70 \\
1\end{array}$ & 36.3 (1.9) & $* * * 2$ & $100.0(\sim 0.0)$ & -3 \\
\hline IS1 & 5.0 & 40.0 & 4.43 & $5.8(0.5)$ & $73.4(22.2)$ & $63.1(4.6)$ & $90.3(3.4)$ \\
\hline IS2 & 5.0 & 40.0 & 4.82 & $86.3(0.1)$ & $99.0(0.6)$ & $25.2(4.1)$ & $28.0(6.0)$ \\
\hline IS3 & 5.0 & 40.0 & 5.87 & $5.6(1.9)$ & $89.4(0.4)$ & 19.9 (4.7) & 23.0 (11.1) \\
\hline IO1 & 5.0 & 40.0 & 7.14 & $1.1(5.6)$ & $89.7(8.8)$ & $11.3(3.5)$ & $4.7(4.8)$ \\
\hline IO2 & 5.0 & 40.0 & 6.58 & $-4.6(0.8)$ & $93.2(1.5)$ & $15.6(3.7)$ & $13.5(6.5)$ \\
\hline IO3 & 5.0 & 40.0 & 5.49 & $-2.4(0.2)$ & $100.0(\sim 0.0)$ & 1.7 (12.4) & 29.4 (3.7) \\
\hline IO4 & 5.0 & 40.0 & 6.44 & $-3.2(0.4)$ & $100.0(\sim 0.0)$ & $-2.4(9.2)$ & 15.0 (5.9) \\
\hline IO5 & $0.7(5.0)$ & 40.0 & 6.29 & $4.8(0.2)$ & $76.4(0.6)$ & $13.4(12.0)$ & $-5.8(8.7)$ \\
\hline IO6 & 1.0 & 40.0 & 6.23 & $3.4(0.4)$ & $89.3(0.8)$ & $8.5(3.3)$ & $13.6(12.5)$ \\
\hline
\end{tabular}

${ }^{1}$ For PIC, average $\mathrm{pH}$ is based on three replicate batch tests instead of six replicate batch tests; ${ }^{2 * * *}$ Signifies that substantially more phosphate-P was present in solution at the completion of the batch test than was present at the beginning of the batch test, thus indicating that PIC itself originally had significant quantities of readily released phosphate; ${ }^{3}$ - Signifies that atrazine was not measured with GC-MS for the PIC batch tests.

Table 3. Batch test screening results for high aluminum content media.

\begin{tabular}{cccccccc}
\hline $\begin{array}{c}\text { Industrial } \\
\text { Product/ } \\
\text { Byproduct }\end{array}$ & $\begin{array}{c}\text { Dry (Wet) } \\
\text { Filter } \\
\text { Material } \\
\text { Amount (g) }\end{array}$ & $\begin{array}{c}\text { Test } \\
\text { Solution } \\
\text { Amount (g) }\end{array}$ & $\begin{array}{c}\text { Avg. } \\
\text { pH }\end{array}$ & $\begin{array}{c}\text { Nitrate-N } \\
\text { Average of } \\
\text { Percent } \\
\text { Removal and } \\
\text { (Std. Dev.) }\end{array}$ & $\begin{array}{c}\text { Phosphate-P } \\
\text { Average of } \\
\text { Percent } \\
\text { Removal and } \\
\text { (Std. Dev.) }\end{array}$ & $\begin{array}{c}\text { Atrazine } \\
\text { Immunoassay } \\
\text { Average of } \\
\text { Percent } \\
\text { Removal and } \\
\text { (Std. Dev.) }\end{array}$ & $\begin{array}{c}\text { Atrazine } \\
\text { GC-MS } \\
\text { Average of } \\
\text { Percent } \\
\text { Removal and } \\
\text { (Std. Dev.) }\end{array}$ \\
\hline AO1 & 5.0 & 40.0 & 6.41 & $-2.6(0.3)$ & $100.0(\sim 0.0)$ & $6.7(8.9)$ & $22.8(12.0)$ \\
AO2 & 5.0 & 40.0 & 6.92 & $4.1(0.3)$ & $94.6(0.5)$ & $12.7(3.1)$ & $-47.8(6.6)$ \\
AO3 & 5.0 & 40.0 & 6.10 & $1.6(0.1)$ & $93.3(2.1)$ & $18.9(3.3)$ & $-9.7(5.9)$ \\
AO4 & 5.0 & 40.0 & 8.25 & $1.8(0.1)$ & $96.5(0.1)$ & $9.7(4.9)$ & $-32.0(17.9)$ \\
AO5 & 5.0 & 40.0 & 8.08 & $1.3(0.3)$ & $94.6(0.4)$ & $10.4(5.6)$ & $-22.7(16.3)$ \\
AO6 & 1.0 & 40.0 & 6.06 & $1.7(0.1)$ & $92.9(0.5)$ & $11.5(7.4)$ & $-24.9(6.4)$ \\
\hline
\end{tabular}

Table 4. Batch test screening results for surfactant modified clay/zeolite.

\begin{tabular}{cccccccc}
\hline $\begin{array}{c}\text { Industrial } \\
\text { Product/ } \\
\text { Byproduct }\end{array}$ & $\begin{array}{c}\text { Dry (Wet) } \\
\text { Filter } \\
\text { Material } \\
\text { Amount (g) }\end{array}$ & $\begin{array}{c}\text { Test } \\
\text { Solution } \\
\text { Amount (g) }\end{array}$ & $\begin{array}{c}\text { Avg. } \\
\text { pH }\end{array}$ & $\begin{array}{c}\text { Nitrate-N } \\
\text { Average of } \\
\text { Percent } \\
\text { Removal and } \\
\text { (Std. Dev.) }\end{array}$ & $\begin{array}{c}\text { Phosphate-P } \\
\text { Average of } \\
\text { Percent } \\
\text { Removal and } \\
\text { (Std. Dev.) }\end{array}$ & $\begin{array}{c}\text { Atrazine } \\
\text { Immunoassay } \\
\text { Average of } \\
\text { Percent } \\
\text { Removal and } \\
\text { (Std. Dev.) }\end{array}$ & $\begin{array}{c}\text { Atrazine } \\
\text { GC-MS } \\
\text { Average of } \\
\text { Percent } \\
\text { Removal and } \\
\text { (Std. Dev.) }\end{array}$ \\
\hline SMC1 & $3.03(5.0)$ & 38.0 & 7.79 & $66.9(0.9)$ & $* *$ & $39.2(11.4)$ & $74.7(3.5)$ \\
SMC2 & $2.29(5.0)$ & 40.0 & 6.25 & $84.5(0.1)$ & $95.3(0.7)$ & $72.6(1.4)$ & $84.8(1.5)$ \\
SMC3 & $2.14(5.0)$ & 40.0 & 8.91 & $3.3(0.3)$ & $97.6(0.2)$ & $37.2(2.3)$ & $40.5(14.4)$ \\
SMZ1 & $4.00(5.0)$ & 40.0 & 8.02 & $48.5(4.8)$ & $* * 4.1$ & $38.4(8.1)$ & $68.9(6.1)$ \\
SMZ2 & $3.80(5.0)$ & 40.0 & 9.33 & $66.0(0.4)$ & $92.3(1.4)$ & $59.9(2.6)$ & $82.8(1.2)$ \\
SMZ3 & $4.02(5.0)$ & 40.0 & 8.62 & $-1.9(0.1)$ & $93.2(0.3)$ & $27.5(6.3)$ & $36.4(15.8)$ \\
\hline
\end{tabular}

*** Signifies that substantially more phosphate-P was present in solution at the completion of the batch test than was present at the beginning of the batch test, thus indicating that the treatment material itself originally contained significant quantities of readily released phosphate. 
Table 5. Batch test screening results for coal combustion residuals.

\begin{tabular}{cccccccc}
\hline $\begin{array}{c}\text { Industrial } \\
\text { Product/ } \\
\text { Byproduct }\end{array}$ & $\begin{array}{c}\text { Dry (Wet) } \\
\text { Filter } \\
\text { Material } \\
\text { Amount (g) }\end{array}$ & $\begin{array}{c}\text { Test Solution } \\
\text { Amount (g) }\end{array}$ & $\begin{array}{c}\text { Avg. } \\
\mathbf{p H}\end{array}$ & $\begin{array}{c}\text { Nitrate-N } \\
\text { Average of } \\
\text { Percent } \\
\text { Removal and } \\
\text { (Std. Dev.) }\end{array}$ & $\begin{array}{c}\text { Phosphate-P } \\
\text { Average of } \\
\text { Percent } \\
\text { Removal and } \\
\text { (Std. Dev.) }\end{array}$ & $\begin{array}{c}\text { Atrazine } \\
\text { Immunoassay } \\
\text { Average of } \\
\text { Percent } \\
\text { Removal and } \\
\text { (Std. Dev.) }\end{array}$ & $\begin{array}{c}\text { Atrazine } \\
\text { GC-MS } \\
\text { Average of } \\
\text { Percent } \\
\text { Removal and } \\
\text { (Std. Dev.) }\end{array}$ \\
\hline CCR1 & 5.0 & 40.0 & 11.85 & $-3.6(0.4)$ & $44.1(9.1)$ & $100.0(\sim 0.0)$ & $100.0(\sim 0.0)$ \\
CCR2 & 5.0 & 40.0 & 6.63 & $-5.2(1.2)$ & $83.2(3.6)$ & $17.8(6.6)$ & $29.6(15.0)$ \\
CCR3 & 5.0 & 40.0 & 12.07 & $13.8(3.1)$ & $96.1(0.1)$ & $20.6(3.9)$ & $32.3(6.2)$ \\
CCR4 & 5.0 & 40.0 & 8.80 & $-3.3(1.5)$ & $96.0(0.8)$ & $14.4(10.4)$ & $16.3(7.6)$ \\
CCR5 & $4.22(5.0)$ & 40.0 & 8.99 & $-2.5(4.4)$ & $88.4(2.7)$ & $100.0(0.0)$ & $100.0(\sim 0.0)$ \\
CCR6 & 5.0 & 40.0 & 6.32 & $-2.5(0.5)$ & $69.3(1.9)$ & $97.2(0.9)$ & $99.3(8.3)$ \\
CCR7 & 5.0 & 40.0 & 7.99 & $-1.4(0.6)$ & $98.5(0.4)$ & $100.0(\sim 0.0)$ & $100.0(\sim 0.0)$ \\
CCR8 & 5.0 & 40.0 & 13.05 & $74.5(1.6)$ & $94.6(2.3)$ & $100.0(\sim 0.0)$ & $100.0(\sim 0.0)$ \\
\hline
\end{tabular}

Table 6. Batch test screening results for spent foundry sands.

\begin{tabular}{cccccccc}
\hline $\begin{array}{c}\text { Industrial } \\
\text { Product/ } \\
\text { Byproduct }\end{array}$ & $\begin{array}{c}\text { Dry (Wet) } \\
\text { Filter } \\
\text { Material } \\
\text { Amount (g) }\end{array}$ & $\begin{array}{c}\text { Test } \\
\text { Solution } \\
\text { Amount (g) }\end{array}$ & $\mathbf{p H}^{\mathbf{1}}$ & $\begin{array}{c}\text { Nitrate-N } \\
\text { Average of } \\
\text { Percent } \\
\text { Removal and } \\
\text { (Std. Dev.) }\end{array}$ & $\begin{array}{c}\text { Phosphate-P } \\
\text { Average of } \\
\text { Percent } \\
\text { Removal and } \\
\text { (Std. Dev.) }\end{array}$ & $\begin{array}{c}\text { Atrazine } \\
\text { Immunoassay } \\
\text { Average of } \\
\text { Percent } \\
\text { Removal and } \\
\text { (Std. Dev.) }\end{array}$ & $\begin{array}{c}\text { Atrazine } \\
\text { GC-MS } \\
\text { Average of } \\
\text { Percent } \\
\text { Removal and } \\
\text { (Std. Dev.) }\end{array}$ \\
\hline FS1 & 5.0 & 40.0 & 8.26 & $1.6(1.0)$ & $95.1(2.4)$ & $18.5(8.7)$ & -2 \\
FS2 & 5.0 & 40.0 & 8.17 & $1.7(1.9)$ & $98.8(0.3)$ & $45.2(4.2)$ & - \\
FS3 & 5.0 & 40.0 & 7.82 & $-1.0(0.2)$ & $94.3(2.5)$ & $76.5(0.9)$ & - \\
FS4 & 5.0 & 40.0 & 7.88 & $2.9(0.7)$ & $94.4(0.5)$ & $59.1(6.8)$ & - \\
FS5 & 5.0 & 40.0 & 7.79 & $2.9(0.6)$ & $97.3(0.8)$ & $49.0(9.2)$ & - \\
FS6 & 5.0 & 40.0 & 7.80 & $0.6(0.6)$ & $96.2(2.8)$ & $50.5(3.7)$ & - \\
FS7 & 5.0 & 40.0 & 7.69 & $2.2(0.7)$ & $94.9(1.9)$ & $35.7(5.3)$ & - \\
\hline
\end{tabular}

${ }^{1}$ The $\mathrm{pH}$ was measured on only one batch test replicate; ${ }^{2}$ - Signifies that atrazine was not measured with GC-MS.

Percent removal standard deviation values of $\sim 0.0 \%$ correspond to an average percent removal of $100 \%$, indicating that solution concentrations for $\mathrm{NO}_{3}{ }^{-}, \mathrm{PO}_{4}{ }^{3-}$, or atrazine at batch test completion were below measurement method detection limits (i.e., essentially all originally present $\mathrm{NO}_{3}{ }^{-}, \mathrm{PO}_{4}{ }^{3-}$, or atrazine had been removed by the filter material). With the exception of gas chromatography-mass spectrometry (GC-MS) measured atrazine for batch tests with high aluminum content media, negative values for average percent $\mathrm{NO}_{3}{ }^{-}, \mathrm{PO}_{4}{ }^{3-}$, or atrazine removal tend to be relatively minor $(0.0 \%$ to $-9.0 \%$ ) and are the result of inherent laboratory measurement variability combined with the filter material having in effect removed no $\mathrm{NO}_{3}{ }^{-}, \mathrm{PO}_{4}{ }^{3-}$, or atrazine. The more negative values of $-48.0 \%$ to $-9 \%$ for GC-MS measured atrazine removals obtained with five of six high aluminum content media did not correspond very well with the average percent atrazine removal measured by immunoassay methods for these same filter materials ( $9 \%$ to $19 \%$ ), which may mean that even very limited dissolution of aluminum oxides could for whatever reason adversely impact GC-MS atrazine measurement.

The notation ${ }^{* * *}$ represents batch tests results where the amount of $\mathrm{PO}_{4}{ }^{3-}$ present in solution at batch test completion is substantially greater, by a factor of two or more, than the $\mathrm{PO}_{4}{ }^{3-}$ present in the original test solution. Consequently, ${ }^{* * *}$ indicates that readily released $\mathrm{PO}_{4}{ }^{3-}$ was initially present with the filter material, which was found to have occurred with eight different industrial products/byproducts (five of the high carbon content media, one of the high iron content media, and two of surfactant modified clay/zeolite). However, ${ }^{* * *}$ does not necessarily imply that the filter material is incapable of removing $\mathrm{PO}_{4}{ }^{3-}$ from agricultural drainage waters. For porous iron composite (PIC), one of the filter materials evaluated in this study, laboratory column tests showed that, once the $\mathrm{PO}_{4}{ }^{3-}$ originally present with PIC leached out, PIC then became very effective removing substantial quantities of drainage water $\mathrm{PO}_{4}{ }^{3-}$ [26].

The initial $\mathrm{pH}$ of the test solution was 7.01. For the seven replicate control batch tests conducted with $40 \mathrm{~g}$ of test solution only (no filter material), the average $\mathrm{pH}$ was 7.38 , the average of the percent 
$\mathrm{NO}_{3}{ }^{-}$removal was $-0.3 \%$ (standard deviation $=1.2 \%$ ), the average of the percent $\mathrm{PO}_{4}{ }^{3-}$ removal was $8.3 \%$ (standard deviation $=9.3 \%$ ), the average of the percent atrazine removal measured by immunoassay methods was $11.1 \%$ (standard deviation $=12.7 \%$ ), and the average of the percent atrazine removal measured by GC-MS was $-10.6 \%$ (standard deviation $=10.3 \%$ ). Results from the control batch tests therefore show that the experimental equipment and procedures alone did not substantially alter solution $\mathrm{pH}$ or cause excessive loss of $\mathrm{NO}_{3}{ }^{-}, \mathrm{PO}_{4}{ }^{3-}$, or atrazine.

Tables 1-6 show a wide range of solution $\mathrm{pH}$ at batch test completion, from 1.97 to 13.05. With an initial test solution $\mathrm{pH}$ of 7.01 and an average control batch $\mathrm{pH}$ of 7.38, clearly many of the industrial product/byproduct filter materials have capacity to significantly alter drainage water $\mathrm{pH}$. Releasing either extremely low or high $\mathrm{pH}$ drainage waters into local streams, rivers, or lakes can cause ecosystem damage. Therefore, the impact on $\mathrm{pH}$ needs to be considered when choosing a particular industrial product/byproduct filter material for drainage water treatment.

Inspection of Tables 1-6 indicate that many of the 58 industrial products/byproducts may have some promise as filter materials for treating $\mathrm{NO}_{3}{ }^{-}, \mathrm{PO}_{4}{ }^{3-}$, and / or atrazine in agricultural drainage waters. Threshold limits can be employed for quantitative determination of which filter materials have potential for drainage water treatment. For this threshold analysis, immunoassay and GC-MS measurements for percent atrazine removal were averaged together, except for the PIC and the spent foundry sand batch tests that had only immunoassay measurements available. Based on a percent contaminant removal criteria of $50 \%$ or greater, Tables $1-6$ show that 13 industrial products/byproducts met this standard for $\mathrm{NO}_{3}{ }^{-}, 48$ met this standard for $\mathrm{PO}_{4}{ }^{3-}$, and 31 met this standard for atrazine. Based on a more selective percent contaminant removal criteria of $75 \%$ or greater, Tables $1-6$ show that seven industrial products/byproducts met this standard for $\mathrm{NO}_{3}{ }^{-}, 44$ met this standard for $\mathrm{PO}_{4}{ }^{3-}$, and 25 met this standard for atrazine. Based on an even more stringent percent contaminant removal criteria of $90 \%$ or greater, Tables 1-6 show that two industrial products/byproducts met this standard for $\mathrm{NO}_{3}{ }^{-}, 37$ met this standard for $\mathrm{PO}_{4}{ }^{3-}$, and 20 met this standard for atrazine. Regardless of the criteria utilized, there were relatively few industrial products/byproducts capable of removing $\mathrm{NO}_{3}{ }^{-}$, while a majority can remove $\mathrm{PO}_{4}{ }^{3-}$. The number of industrial products/byproducts potentially capable of removing atrazine is between the number capable of $\mathrm{NO}_{3}{ }^{-}$removal and the number capable of $\mathrm{PO}_{4}{ }^{3-}$ removal. Consequently, if the drainage water treatment goal is to remove only one of the agricultural contaminants $\left(\mathrm{NO}_{3}{ }^{-}, \mathrm{PO}_{4}{ }^{3-}\right.$, or atrazine), there are a large number of possible filter material options for $\mathrm{PO}_{4}{ }^{3-}$, fewer for atrazine, and fewer still for $\mathrm{NO}_{3}{ }^{-}$.

If the goal were for drainage water treatment of all three contaminants $\left(\mathrm{NO}_{3}{ }^{-}, \mathrm{PO}_{4}{ }^{3-}\right.$, and atrazine), considering a percent removal standard of $50 \%$ or greater, Tables 1-6 indicate that five filter materials (AC1, SMI3, SMC2, SMZ2, and CCR8) may have this capability. With this same $50 \%$ or greater standard, eight of the industrial products/byproducts may have capability for combined $\mathrm{NO}_{3}{ }^{-}$ and $\mathrm{PO}_{4}{ }^{3-}$ removal, 21 of the industrial products/byproducts may have capability for combined $\mathrm{PO}_{4}{ }^{3-}$ and atrazine removal, and nine of the industrial products/byproducts may have capability for combined $\mathrm{NO}_{3}{ }^{-}$and atrazine removal. Therefore, the number of options for drainage water treatment of either two or all three contaminants might be somewhat limited if only one industrial product/byproduct filter material is being contemplated for use. The number of options for combined treatment of more than one drainage water contaminant will increase substantially if mixing two or more of the industrial product/byproduct filter materials were considered (assuming chemical compatibility) or the filter treatment system were designed using two separate stages, with each stage containing a different industrial product/byproduct filter material.

Due to the large differences in chemical composition/structure of members within each of the six industrial product/byproduct categories tested, it is somewhat difficult to draw meaningful conclusions regarding $\mathrm{pH}$ and removal behavior of $\mathrm{NO}_{3}{ }^{-}, \mathrm{PO}_{4}{ }^{3-}$, or atrazine based just on category alone. However, some trends were noted. Batch test $\mathrm{pH}$ was consistent within a narrow range of 7.69 to 8.26 for spent foundry sands, while within, each of the other five categories, $\mathrm{pH}$ was much more variable (Tables 1-6). Figure 2 depicts, by category, the number of industrial products/byproducts 
removing $50 \%, 75 \%$, or $90 \%$ of $\mathrm{NO}_{3}{ }^{-}, \mathrm{PO}_{4}{ }^{3-}$, or atrazine. The majority of filter materials having possible capability for drainage water $\mathrm{NO}_{3}{ }^{-}$treatment were found in the high carbon content media, high iron content media, and surfactant modified clay/zeolite categories. Most members in each of the six industrial product/byproduct categories show some promise with respect to $\mathrm{PO}_{4}{ }^{3-}$ removal. All of the high carbon content media filter materials, along with most of the surfactant modified clays / zeolites and coal combustion residuals, exhibited at least limited potential ( $\geq 50 \%$ removal) for atrazine treatment.
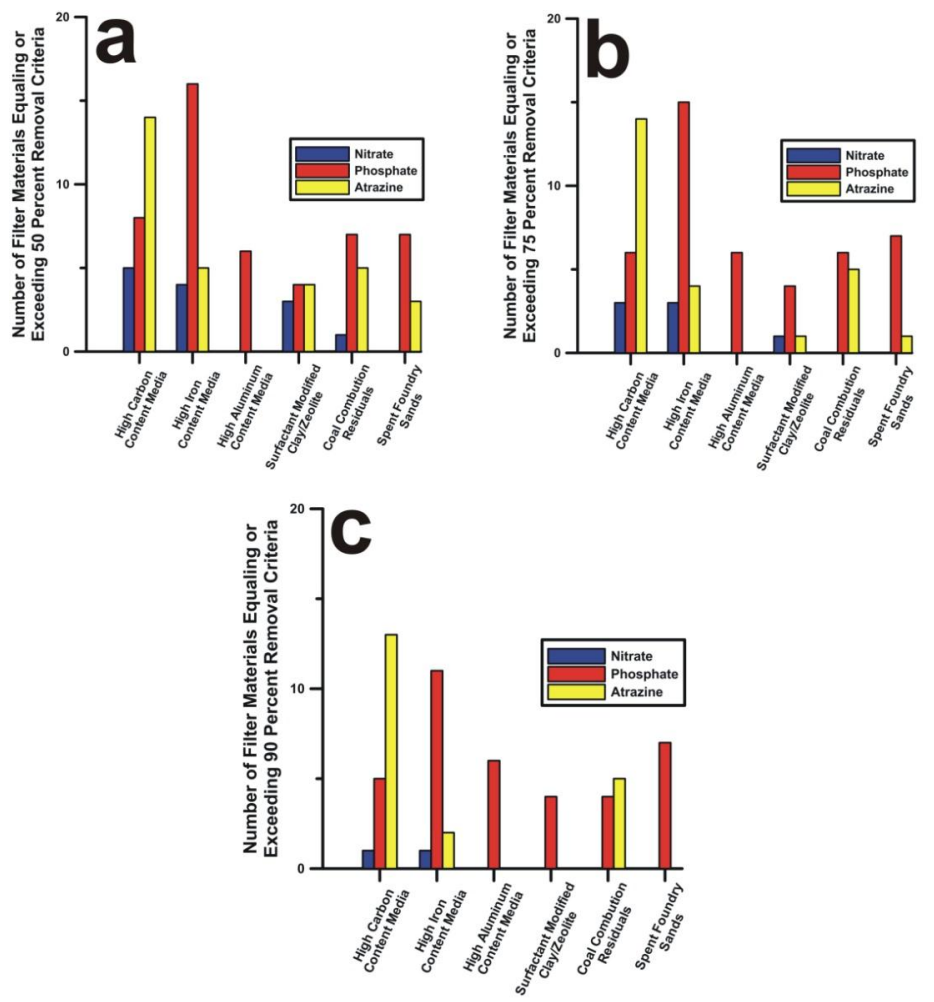

Figure 2. Number of filter materials, by industrial product/byproduct category, removing: (a) 50\%; (b) $75 \%$; or (c) $90 \%$ of $\mathrm{NO}_{3}{ }^{-}, \mathrm{PO}_{4}{ }^{3-}$, or atrazine. Note: Atrazine numbers are based on averaging immunoassay and GC-MS measurements together, except for the PIC and the spent foundry sand batch tests that had only immunoassay measurements available.

Again, the purpose the study was to delineate potential industrial product/byproduct filter materials warranting further investigation for agricultural drainage water treatment. The processes by which filter materials can remove $\mathrm{NO}_{3}{ }^{-}, \mathrm{PO}_{4}{ }^{3-}$, and/or atrazine were previously described in the Introduction section. Although beyond the scope of this study, isolating the predominant process or processes by which a particular industrial product/byproduct filter material removes a particular contaminant (i.e., $\mathrm{NO}_{3}{ }^{-}, \mathrm{PO}_{4}{ }^{3-}$, or atrazine) is important information and will require extensive laboratory examination with adsorption isotherm and reaction kinetics batch tests. However, some generalizations for the filter materials tested regarding $\mathrm{NO}_{3}{ }^{-}, \mathrm{PO}_{4}{ }^{3-}$, or atrazine removal mechanisms can be postulated. Nitrate removal by activated carbon (AC1, AC2, AC3, AC4, and AC5) and surfactant modified clay/zeolite (SMC1, SMC2, SMZ1, and SMZ2) is likely due to adsorption caused by electrostatic attraction between negatively charged $\mathrm{NO}_{3}{ }^{-}$ions and positively charged surfaces on filter material particles [20,21,41]. The sulfur modified iron filter materials (SMI1, SMI2, and SMI3) probably removed $\mathrm{NO}_{3}{ }^{-}$via oxidation/reduction reactions that convert $\mathrm{NO}_{3}{ }^{-}$to ammonia/ammonium, $\mathrm{NH}_{3} / \mathrm{NH}_{4}{ }^{+}$, or nitrogen gas, $\mathrm{N}_{2}$ [22-26]. Phosphate removal by high iron content media, high aluminum content media, coal combustion residuals, and spent foundry sands could be the result of either the formation of low solubility chemical precipitates (i.e., aluminum, calcium, iron, and magnesium-phosphate 
compounds) [28-31] or direct $\mathrm{PO}_{4}{ }^{3-}$ adsorption via ligand exchange at oxygen containing functional group sites present along surfaces of filter material particles [29-33]. Phosphate removal by the high carbon content media and surfactant modified clay/zeolite is probably due to ligand exchange adsorption $[29,33,57,58]$ and/or electrostatic attraction between negatively charged $\mathrm{PO}_{4}{ }^{3-}$ ions and positively charged filter material surfaces [34-36,41]. For the high carbon content media, surfactant modified clay/zeolite, coal combustion residuals, and spent foundry sand filter materials exhibiting capability for atrazine removal, the most likely removal mechanism is adsorption at filter material particle surfaces caused by London-van der Waals dispersion forces or hydrophobic interactions [37,41]. Atrazine removal by some of the high iron content media (ZVI1, ZVI2, SMI3, and PIC) is probably due to reductive dechlorination [38-40]. Atrazine losses during the control batch tests were minimal, thereby indicating that photodegradation did not play a significant role in atrazine removal.

Furthermore, full assessment regarding the feasibility for using a particular industrial product/byproduct or combination of industrial products/byproducts within a filter treatment system for removing $\mathrm{NO}_{3}{ }^{-}, \mathrm{PO}_{4}{ }^{3-}$, and/or atrazine from drainage waters will also require hydraulic conductivity measurements, long duration variable flow rate saturated column experiments, regeneration capacity evaluation, determining the leaching potential for any contaminants originally present with the filter material, pilot scale field demonstrations, and economic analysis. In particular, filter treatment system design will necessitate follow-up testing of potential industrial product/byproduct materials that specifically includes hydraulic conductivity measurements, adsorption isotherm batch tests, reaction kinetics batch tests, and long duration variable flow rate saturated column experiments. The hydraulic conductivity measurements will provide insight on the flow rate capability of the filter material. The reaction kinetics batch tests and long duration variable flow rate saturated column experiments will quantify the period of contact (i.e., residence time) needed by the filter material to effectively remove $\mathrm{NO}_{3}{ }^{-}, \mathrm{PO}_{4}{ }^{3-}$, and/or atrazine. The adsorption isotherm batch tests and long duration variable flow rate saturated column experiments will establish the total $\mathrm{NO}_{3}{ }^{-}, \mathrm{PO}_{4}{ }^{3-}$, and/or atrazine removal capacity of the filter material. With knowledge of drainage system flow rates, and filter material characteristics (i.e., flow rate capability, residence time for contaminant removal, and total contaminant removal capacity), determinations can be made as to the size of the filter treatment system and the amount industrial product/byproduct material needed to fill it, along with the regularity in which the filter material will need to be replaced or regenerated. A limited amount of additional drainage water treatment research has been conducted on a very select few of the industrial products/byproducts tested in this study [25,26,59-62]; however, most of the other filter materials that exhibited potential remain in need of further investigation.

\section{Summary and Conclusions}

Discharge of agricultural drainage waters containing nitrate $\left(\mathrm{NO}_{3}{ }^{-}\right)$, phosphate $\left(\mathrm{PO}_{4}{ }^{3-}\right)$, and pesticides can cause adverse environmental impacts on local, regional, and national scales. An in-line filter treatment system located on the main collector pipe near the subsurface drainage system outlet could be a viable means for removing $\mathrm{NO}_{3}{ }^{-}, \mathrm{PO}_{4}{ }^{3-}$, and pesticides from drainage waters before these waters are released into local streams, rivers, and lakes. Therefore, choosing a suitable filter material for this type of water treatment system will be critical for effective removal of $\mathrm{NO}_{3}{ }^{-}, \mathrm{PO}_{4}{ }^{3-}$, and pesticides.

There are many industrial products/byproducts that could serve as filter materials for drainage water treatment. For this reason, laboratory batch test screening was conducted on 58 industrial product/byproduct filter materials grouped into six categories: (1) high carbon content media; (2) high iron content media; (3) high aluminum content media; (4) surfactant modified clay/zeolite; (5) coal combustion residuals; and (6) spent foundry sands. Results showed that many of the industrial product/byproduct filter materials have capacity to significantly alter drainage water $\mathrm{pH}$, which needs to be taken into account when choosing a filter material, because releasing either extremely low or high $\mathrm{pH}$ drainage waters into local waterways could cause ecosystem damage. 
With regard to nutrient and pesticide treatment, based on a percent contaminant removal criteria of $50 \%$ or greater, 13 industrial products/byproducts met this standard for $\mathrm{NO}_{3}{ }^{-}, 48$ met this standard for $\mathrm{PO}_{4}{ }^{3-}$, and 31 met this standard for the organochloride pesticide, atrazine. Based on a more selective percent contaminant removal criteria of $75 \%$ or greater, seven industrial products/byproducts met this standard for $\mathrm{NO}_{3}{ }^{-}, 44$ met this standard for $\mathrm{PO}_{4}{ }^{3-}$, and 25 met this standard for atrazine. Based on an even more stringent percent contaminant removal criteria of $90 \%$ or greater, two industrial products/byproducts met this standard for $\mathrm{NO}_{3}{ }^{-}, 37$ met this standard for $\mathrm{PO}_{4}{ }^{3-}$, and 20 met this standard for atrazine. Using a $50 \%$ or greater contaminant removal criteria, five of the industrial product/byproduct filter materials exhibited potential for removing $\mathrm{NO}_{3}{ }^{-}, \mathrm{PO}_{4}{ }^{3-}$, and atrazine together; eight showed capability for combined $\mathrm{NO}_{3}{ }^{-}$and $\mathrm{PO}_{4}{ }^{3-}$ removal; 21 showed capability for combined $\mathrm{PO}_{4}{ }^{3-}$ and atrazine removal; and nine showed capability for combined $\mathrm{NO}_{3}{ }^{-}$and atrazine removal. Consequently, there are quite a few possibilities for treating a single drainage water contaminant (e.g., $\mathrm{NO}_{3}{ }^{-}, \mathrm{PO}_{4}{ }^{3-}$, or atrazine); however, effective treatment of more than one drainage water contaminant simultaneously may require consideration with respect to the mixing of two or more of the industrial product/byproduct filter materials together (assuming chemical compatibility) or installation of a two-stage filter treatment system, with each stage containing a different industrial product/byproduct filter material.

Consequently, a number of industrial product/byproduct filter materials were determined to have potential for use in removing $\mathrm{NO}_{3}{ }^{-}, \mathrm{PO}_{4}{ }^{3-}$, and/or atrazine from drainage waters. For a complete drainage water treatment feasibility evaluation of the most promising of these industrial product/byproduct filter materials, much more extensive research is needed. This additional investigation should include adsorption isotherm and reaction kinetics batch tests, hydraulic conductivity measurements, long duration variable flow rate saturated column experiments, regeneration capacity evaluation, determining the leaching potential for any contaminants originally present with the filter material, pilot scale field demonstrations, and economic analysis.

Conflicts of Interest: The author declares no conflict of interest.

\section{Appendix A}

Batch test results with nitrate-nitrogen, phosphate-phosphorous and atrazine removal calculated as milligrams of contaminant removed per gram of filter material.

Table A1. Batch test screening results for high carbon content media.

\begin{tabular}{|c|c|c|c|c|c|c|c|}
\hline $\begin{array}{l}\text { Industrial } \\
\text { Product/ } \\
\text { Byproduct }\end{array}$ & $\begin{array}{c}\text { Dry (Wet) } \\
\text { Filter } \\
\text { Material } \\
\text { Amount (g) }\end{array}$ & $\begin{array}{l}\text { Test } \\
\text { Solution } \\
\text { Amount } \\
\quad(g)\end{array}$ & Avg. pH & $\begin{array}{l}\text { Nitrate-N } \\
\text { Average } \\
\text { Removal } \\
(\mathrm{mg} / \mathrm{g})\end{array}$ & $\begin{array}{l}\text { Phosphate-P } \\
\text { Average } \\
\text { Removal } \\
\text { (mg/g) }\end{array}$ & $\begin{array}{c}\text { Atrazine } \\
\text { Immunoassay } \\
\text { Average Removal } \\
(\mathrm{mg} / \mathrm{g})\end{array}$ & $\begin{array}{c}\text { Atrazine GC-MS } \\
\text { Average Removal } \\
\text { (mg/g) }\end{array}$ \\
\hline COAL1 & 5.0 & 38.0 & 6.36 & 0.025 & 0.00180 & 0.00303 & 0.00304 \\
\hline COAL2 & 5.0 & 38.0 & 2.91 & 0.359 & $* * *$ & 0.00272 & 0.00278 \\
\hline COAL3 & 5.0 & 38.0 & 7.98 & $\sim 0$ & 0.00190 & 0.00304 & 0.00304 \\
\hline COAL6 & 5.0 & 38.0 & 6.64 & $\sim 0$ & 0.00099 & 0.00276 & 0.00287 \\
\hline COKE1 & 5.0 & 40.0 & 7.25 & 0.015 & 0.00180 & 0.00315 & 0.00320 \\
\hline COKE2 & 5.0 & 39.0 & 7.16 & 0.016 & 0.00004 & 0.00226 & 0.00271 \\
\hline CHAR & 5.0 & 38.0 & 8.42 & $\sim 0$ & $* * *$ & 0.00302 & 0.00304 \\
\hline AC1 & 5.0 & 38.0 & 9.01 & 0.236 & 0.00134 & 0.00303 & 0.00304 \\
\hline AC2 & 5.0 & 40.0 & 10.13 & 0.206 & $* * *$ & 0.00320 & 0.00320 \\
\hline
\end{tabular}

*** Signifies that substantially more phosphate-P was present in solution at the completion of the batch test than was present at the beginning of the batch test, thus indicating that the treatment material itself originally had significant quantities of readily released phosphate. 
Table A2. Batch test screening results for high iron content media.

\begin{tabular}{|c|c|c|c|c|c|c|c|}
\hline $\begin{array}{l}\text { Industrial } \\
\text { Product/ } \\
\text { Byproduct }\end{array}$ & $\begin{array}{c}\text { Dry (Wet) } \\
\text { Filter } \\
\text { Material } \\
\text { Amount (g) }\end{array}$ & $\begin{array}{l}\text { Test } \\
\text { Solution } \\
\text { Amount } \\
\text { (g) }\end{array}$ & Avg. pH & $\begin{array}{l}\text { Nitrate-N } \\
\text { Average } \\
\text { Removal } \\
(\mathrm{mg} / \mathrm{g})\end{array}$ & $\begin{array}{l}\text { Phosphate-P } \\
\text { Average } \\
\text { Removal } \\
\text { (mg/g) }\end{array}$ & $\begin{array}{c}\text { Atrazine } \\
\text { Immunoassay } \\
\text { Average Removal } \\
(\mathrm{mg} / \mathrm{g})\end{array}$ & $\begin{array}{c}\text { Atrazine GC-MS } \\
\text { Average Removal } \\
\text { (mg/g) }\end{array}$ \\
\hline ZVI1 & $4.9(5.0)$ & 40.0 & 9.21 & 0.040 & 0.00195 & 0.00286 & 0.00297 \\
\hline ZVI2 & $4.8(5.0)$ & 40.0 & 9.58 & 0.025 & 0.00207 & 0.00317 & 0.00319 \\
\hline ZVI3 & $4.3(5.0)$ & 40.0 & 9.54 & $\sim 0$ & 0.00228 & 0.00020 & 0.00046 \\
\hline SMI2 & 5.0 & 40.0 & 9.12 & 0.301 & 0.00192 & 0.00086 & 0.00118 \\
\hline SMI3 & 5.0 & 40.0 & 3.09 & 0.394 & 0.00188 & 0.00198 & 0.00264 \\
\hline PIC & 5.0 & 40.0 & $10.70^{1}$ & 0.145 & $* * * 2$ & 0.00320 & -3 \\
\hline IS1 & 5.0 & 40.0 & 4.43 & 0.023 & 0.00147 & 0.00202 & 0.00288 \\
\hline IS2 & 5.0 & 40.0 & 4.82 & 0.345 & 0.00198 & 0.00081 & 0.00090 \\
\hline IO4 & 5.0 & 40.0 & 6.44 & $\sim 0$ & 0.00200 & $\sim 0$ & 0.00048 \\
\hline IO5 & $0.7(5.0)$ & 40.0 & 6.29 & 0.137 & 0.01091 & 0.00306 & $\sim 0$ \\
\hline IO6 & 1.0 & 40.0 & 6.23 & 0.068 & 0.00893 & 0.00136 & 0.00218 \\
\hline
\end{tabular}

${ }^{1}$ For PIC, average $\mathrm{pH}$ is based on three replicate batch tests instead of six replicate batch tests; ${ }^{2 * * *}$ Signifies that substantially more phosphate-P was present in solution at the completion of the batch test than was present at the beginning of the batch test, thus indicating that PIC itself originally had significant quantities of readily released phosphate; ${ }^{3}$ - Signifies that atrazine was not measured with GC-MS for the PIC batch tests.

Table A3. Batch test screening results for high aluminum content media.

\begin{tabular}{cccccccc}
\hline $\begin{array}{c}\text { Industrial } \\
\text { Product/ } \\
\text { Byproduct }\end{array}$ & $\begin{array}{c}\text { Dry (Wet) } \\
\text { Filter } \\
\text { Material } \\
\text { Amount (g) }\end{array}$ & $\begin{array}{c}\text { Test } \\
\text { Solution } \\
\text { Amount } \\
\text { (g) }\end{array}$ & Avg. $\mathbf{p H}$ & $\begin{array}{c}\text { Nitrate-N } \\
\text { Average } \\
\text { Removal } \\
\text { (mg/g) }\end{array}$ & $\begin{array}{c}\text { Phosphate-P } \\
\text { Average } \\
\text { Removal } \\
\text { (mg/g) }\end{array}$ & $\begin{array}{c}\text { Atrazine } \\
\text { Immunoassay } \\
\text { Average Removal } \\
\text { (mg/g) }\end{array}$ & $\begin{array}{c}\text { Atrazine GC-MS } \\
\text { Average Removal } \\
\text { (mg/g) }\end{array}$ \\
\hline AO1 & 5.0 & 40.0 & 6.41 & $\sim 0$ & 0.00200 & 0.00021 & $\sim 0$ \\
AO2 & 5.0 & 40.0 & 6.92 & 0.016 & 0.00189 & 0.00041 & $\sim 0$ \\
AO3 & 5.0 & 40.0 & 6.10 & 0.006 & 0.00187 & 0.00060 & $\sim 00031$ \\
AO4 & 5.0 & 40.0 & 8.25 & 0.007 & 0.00193 & 0.00033 & $\sim 0$ \\
AO5 & 5.0 & 40.0 & 8.08 & 0.005 & 0.00189 & 0.00184 & $\sim 0$ \\
AO6 & 1.0 & 40.0 & 6.06 & 0.034 & 0.00929 & \\
\hline
\end{tabular}

Table A4. Batch test screening results for surfactant modified clay/zeolite.

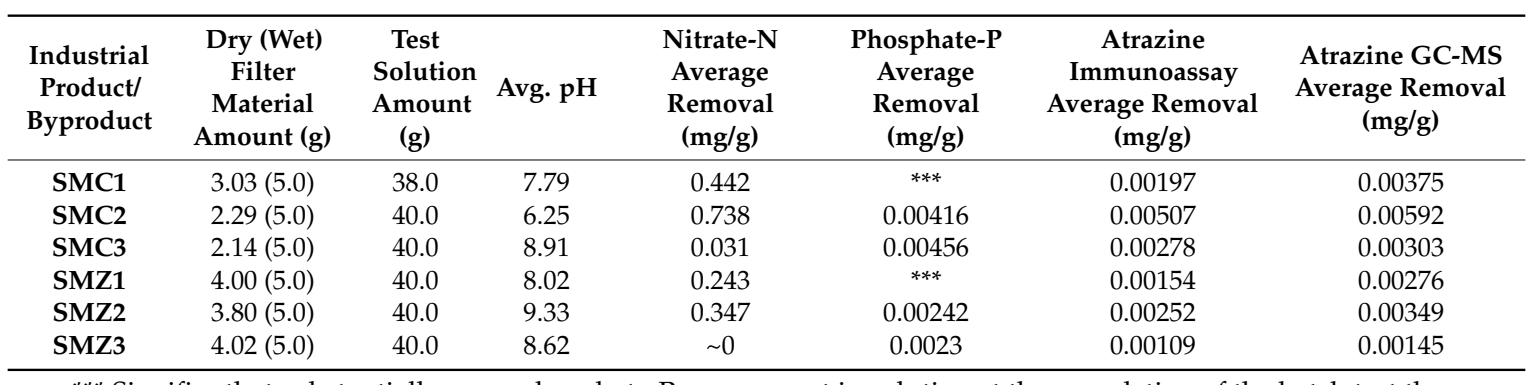

*** Signifies that substantially more phosphate-P was present in solution at the completion of the batch test than was present at the beginning of the batch test, thus indicating that the treatment material itself originally contained significant quantities of readily released phosphate. 
Table A5. Batch test screening results for coal combustion residuals.

\begin{tabular}{cccccccc}
\hline $\begin{array}{c}\text { Industrial } \\
\text { Product/ } \\
\text { Byproduct }\end{array}$ & $\begin{array}{c}\text { Dry (Wet) } \\
\text { Filter } \\
\text { Material } \\
\text { Amount (g) }\end{array}$ & $\begin{array}{c}\text { Test } \\
\text { Solution } \\
\text { Amount } \\
\mathbf{( g )}\end{array}$ & Avg. pH & $\begin{array}{c}\text { Nitrate-N } \\
\text { Average } \\
\text { Removal } \\
\text { (mg/g) }\end{array}$ & $\begin{array}{c}\text { Phosphate-P } \\
\text { Average } \\
\text { Removal } \\
\text { (mg/g) }\end{array}$ & $\begin{array}{c}\text { Atrazine } \\
\text { Immunoassay } \\
\text { Average Removal } \\
\text { (mg/g) }\end{array}$ & $\begin{array}{c}\text { Atrazine GC-MS } \\
\text { Average Removal } \\
\text { (mg/g) }\end{array}$ \\
\hline CCR1 & 5.0 & 40.0 & 11.85 & $\sim 0$ & 0.00088 & 0.00320 & 0.00320 \\
CCR2 & 5.0 & 40.0 & 6.63 & $\sim 0$ & 0.00166 & 0.00057 & 0.00095 \\
CCR3 & 5.0 & 40.0 & 12.07 & $\sim 0$ & 0.00192 & 0.00066 & 0.00103 \\
CCR4 & 5.0 & 40.0 & 8.80 & $\sim 0$ & 0.00192 & 0.0046 & 0.00379 \\
CCR5 & $4.22(5.0)$ & 40.0 & 8.99 & $\sim 0$ & 0.00209 & 0.00311 & 0.00318 \\
CCR6 & 5.0 & 40.0 & 6.32 & $\sim 0$ & 0.00139 & 0.00320 \\
CCR7 & 5.0 & 40.0 & 7.99 & $\sim 0$ & 0.00197 & 0.00320 \\
CCR8 & 5.0 & 40.0 & 13.05 & 0.298 & 0.00189 & 0.00320 \\
\hline
\end{tabular}

Table A6. Batch test screening results for spent foundry sands.

\begin{tabular}{|c|c|c|c|c|c|c|c|}
\hline $\begin{array}{l}\text { Industrial } \\
\text { Product/ } \\
\text { Byproduct }\end{array}$ & $\begin{array}{l}\text { Dry (Wet) } \\
\text { Filter } \\
\text { Material } \\
\text { Amount (g) }\end{array}$ & $\begin{array}{l}\text { Test } \\
\text { Solution } \\
\text { Amount } \\
\text { (g) }\end{array}$ & Avg. $\mathrm{pH}^{1}$ & $\begin{array}{l}\text { Nitrate-N } \\
\text { Average } \\
\text { Removal } \\
(\mathrm{mg} / \mathrm{g})\end{array}$ & $\begin{array}{c}\text { Phosphate-P } \\
\text { Average } \\
\text { Removal } \\
\text { (mg/g) }\end{array}$ & $\begin{array}{c}\text { Atrazine } \\
\text { Immunoassay } \\
\text { Average Removal } \\
(\mathrm{mg} / \mathrm{g})\end{array}$ & $\begin{array}{c}\text { Atrazine GC-MS } \\
\text { Average Removal } \\
\text { (mg/g) }\end{array}$ \\
\hline FS1 & 5.0 & 40.0 & 8.26 & 0.006 & 0.00190 & 0.00059 & -2 \\
\hline FS2 & 5.0 & 40.0 & 8.17 & 0.007 & 0.00198 & 0.00144 & - \\
\hline FS3 & 5.0 & 40.0 & 7.82 & $\sim 0$ & 0.00189 & 0.00244 & - \\
\hline FS6 & 5.0 & 40.0 & 7.80 & 0.002 & 0.00192 & 0.00162 & - \\
\hline FS7 & 5.0 & 40.0 & 7.69 & 0.009 & 0.00190 & 0.00114 & - \\
\hline
\end{tabular}

${ }^{1}$ The $\mathrm{pH}$ was measured on only one batch test replicate; ${ }^{2}$ - Signifies that atrazine was not measured with GC-MS.

\section{References}

1. Goolsby, D.A.; Battaglin, W.A. Nitrogen in the Mississippi Basin-Estimating Sources and Predicting Flux to the Gulf of Mexico; U.S. Geological Survey Fact Sheet135-00; USGS: Reston, VA, USA, 2000; pp. 1-6.

2. Myers, D.N.; Thomas, M.A.; Frey, J.W.; Rheaume, S.J.; Button, D.T. Water quality in the Lake Erie-Lake Saint Clair drainages: Michigan, Ohio, Indiana, New York, and Pennsylvania, 1996-1998; U.S. Geological Survey Circular 1203; USGS: Denver, Colorado, USA, 2000; pp. 1-35.

3. Sylvan, J.B.; Dortch, Q.; Nelson, D.M.; Maier Brown, A.F.; Morrison, W.; Ammerman, J.W. Phosphorous limits phytoplankton growth on the Louisiana Shelf during the period of hypoxia formation. Environ. Sci. Technol. 2006, 40, 7548-7553. [CrossRef] [PubMed]

4. Scavia, D.; Donnelly, K.A. Reassessing hypoxia forecasts for the Gulf of Mexico. Environ. Sci. Technol. 2007, 41, 8111-8177. [CrossRef] [PubMed]

5. Alexander, R.B.; Smith, R.A.; Schwarz, G.E.; Boyer, E.W.; Nolan, J.V.; Brakebill, J.W. Differences in phosphorous and nitrogen delivery to the Gulf of Mexico from the Mississippi River Basin. Environ. Sci. Technol. 2008, 42, 822-830. [CrossRef] [PubMed]

6. Zucker, L.A.; Brown, L.C. Agricultural Drainage: Water Quality Impacts and Subsurface Drainage Studies in the Midwest; OSU Extension Bulletin 871; Ohio State University: Columbus, OH, USA, 1998; pp. 1-40.

7. Kalita, P.K.; Algoazany, A.S.; Mitchell, J.K.; Cooke, R.A.; Hirschi, M.C. Subsurface water quality from a flat tile-drained watershed in Illinois U.S.A. Agric. Ecosyst. Environ. 2006, 115, 183-193. [CrossRef]

8. Kalita, P.K.; Cooke, R.A.; Anderson, S.M.; Hirschi, M.C.; Mitchell, J.K. Subsurface drainage and water quality: The Illinois experience. Trans. ASABE 2007, 50, 1651-1656. [CrossRef]

9. Kladivko, E.J.; Van Scoyoc, G.E.; Monke, E.J.; Oates, K.M.; Pask, W. Pesticide and nutrient movement into subsurface tile drains on a silt loam soil in Indiana. J. Environ. Qual. 1991, 20, 264-270. [CrossRef]

10. Beauchemin, S.; Simard, R.R.; Cluis, D. Forms and concentration of phosphorus in drainage water of twenty-seven tile-drained soils. J. Environ. Qual. 1998, 27, 721-728. [CrossRef]

11. Sims, J.T.; Simard, R.R.; Joern, B.C. Phosphorus loss in agricultural drainage: Historical perspective and current research. J. Environ. Qual. 1998, 27, 277-293. [CrossRef] 
12. Laubel, A.; Jacobsen, O.H.; Kronvang, B.; Grant, R.; Andersen, H.E. Subsurface drainage loss of particles and phosphorus from field plot experiments and a tile-drained catchment. J. Environ. Qual. 1999, 28, 576-584. [CrossRef]

13. Lu, J. Characteristics of phosphorus components in drainage water. Bull. Environ. Contam. Toxicol. 2004, 72, 289-297. [CrossRef] [PubMed]

14. Kinley, R.D.; Gordon, R.J.; Stratton, G.W.; Patterson, G.T.; Hoyle, J. Phosphorus losses through agricultural tile drainage in Nova Scotia, Canada. J. Environ. Qual. 2007, 36, 469-477. [CrossRef] [PubMed]

15. Dousset, S.; Babut, M.; Andreux, F.; Schiavon, M. Alachlor and bentazone losses from subsurface drainage of two soils. J. Environ. Qual. 2004, 33, 294-301. [CrossRef] [PubMed]

16. Gaynor, J.D.; MacTavish, D.C.; Findlay, W.I. Atrazine and metolachor loss in surface and subsurface runoff from three tillage treatments in corn. J. Environ. Qual. 1995, 24, 246-256. [CrossRef]

17. Kladivko, E.J.; Grochulska, J.; Turco, R.F.; Van Scoyoc, G.E.; Eigel, J.D. Pesticide and nitrate transport into subsurface tile drains of different spacings. J. Environ. Qual. 1999, 28, 997-1004. [CrossRef]

18. Yuan, Y.; Mitchell, J.K.; Walker, S.E.; Hirschi, M.C.; Cooke, R.A.C. Atrazine losses from corn fields in the Little Vermilion River Watershed in east central Illinois. Appl. Eng. Agric. 2000, 16, 51-56. [CrossRef]

19. Gaynor, J.D.; Tan, C.S.; Drury, C.F.; Van Wesenbeeck, I.J.; Welacky, T.W. Atrazine in surface and subsurface runoff as affected by cultural practices. Water Qual. J. Can. 1995, 30, 513-531.

20. Wong, M.T.F.; Huges, R.; Rowell, D.L. Retarded leaching of nitrate in acid soils from the tropics: Measurement of effective anion exchange capacity. J. Soil Sci. 1990, 41, 655-663. [CrossRef]

21. Allred, B.J.; Bigham, J.M.; Brown, G.O. The impact of clay mineralogy on nitrate mobility under unsaturated flow conditions. Vadose Zone J. 2007, 6, 221-232. [CrossRef]

22. Choe, S.; Chang, Y.; Hwang, K.; Khim, J. Kinetics of reductive denitrification by nanoscale zero-valent iron. Chemosphere 2000, 41, 1307-1311. [CrossRef]

23. Westerhoff, P.; James, J. Nitrate removal in zero-valent iron packed columns. Water Res. 2003, 37, $1818-1830$. [CrossRef]

24. Biswas, S.; Bose, P. Zero-valent iron-assissted autotrophic denitrification. J. Environ. Eng. 2005, 131, $1212-1220$. [CrossRef]

25. Allred, B.J. Laboratory evaluation of zero valent iron and sulfur-modified iron for agricultural drainage water treatment. Groundw. Monit. Remedat. 2012, 32, 81-95. [CrossRef]

26. Allred, B.J. Laboratory evaluation of porous iron composite for agricultural drainage water filter treatment. Trans. ASABE 2012, 55, 1683-1697. [CrossRef]

27. Lide, D.R. (Ed.) Solubility Chart. In CRC Handbook of Chemistry and Physics, 75th ed.; CRC Press: Boca Raton, FL, USA, 1994; Section 8; pp. 60-62.

28. Stumm, W.; Morgan, J.J. Aquatic Chemistry: An Introduction Emphasizing Chemical Equilibria in Natural Waters, 2nd ed.; John Wiley \& Sons: New York, NY, USA, 1981; pp. 282-285.

29. Bohn, H.L.; McNeal, B.L.; O'Connor, G.A. Soil Chemistry, 2nd ed.; John Wiley \& Sons: New York, NY, USA, 1985; pp. 190-194.

30. Li, L.; Stanforth, R. Distinguishing adsorption and surface precipitation of phosphate on goethite $(\alpha-\mathrm{FeOOH})$. J. Colloid Int. Sci. 2000, 230, 12-21. [CrossRef] [PubMed]

31. Robertson, W.D.; Lombardo, P.S. Treatment of wastewater phosphate by reductive dissolution of iron: Use of ferric oxyhydroxide media. J. Environ. Qual. 2011, 40, 1955-1962. [CrossRef] [PubMed]

32. Goldberg, S. Chemical modeling of anion competition on goethite using the constant capacitance model. Soil Sci. Soc. Am. J. 1985, 49, 851-856. [CrossRef]

33. McBride, M.B. Environmental Chemistry of Soils; Oxford University Press, Inc.: New York, NY, USA, 1994; pp. 135-139, 372-378.

34. Barrow, N.J.; Bowden, J.W.; Posner, A.M.; Quirk, J.P. Describing the effects of electrolyte on adsorption of phosphate by a variable charge surface. Aust. J. Soil Res. 1980, 18, 395-404. [CrossRef]

35. Arai, Y.; Sparks, D.L. Phosphate reaction dynamics in soils and soil components: A multiscale approach. In Advances in Agronomy; Sparks, D.L., Ed.; Academic Press: San Diego, CA, USA, 2007; pp. 135-179.

36. Wang, Y.; Jiang, J.; Xu, R.; Tiwari, D. Phosphate adsorption at variable charge soil/water interfaces as influenced by ionic strength. Aust. J. Soil Res. 2009, 47, 529-536. [CrossRef]

37. Rosen, M.J. Surfactants and Interfacial Phenomena, 2nd ed.; John Wiley \& Sons: New York, NY, USA, 1989; pp. 39-42. 
38. Dombek, T.; Dolan, E.; Schultz, J.; Klaruo, D. Rapid reductive dechlorination of atrazine by zero-valent iron under acid conditions. Environ. Pollut. 2001, 111, 21-27. [CrossRef]

39. Kim, G.; Jeong, W.; Choe, S. Impact of $\mathrm{pH}$ buffer capacity of sediment on dechlorination of atrazine using zero valent iron. J. Environ. Sci. Health Part B 2007, 42, 287-295. [CrossRef] [PubMed]

40. Satapanajaru, T.; Anurakpongsatorn, P.; Pengthamkeerati, P.; Boparai, H. Remediation of atrazine-contaminated soil and water by nano zerovalent iron. Water Air Soil Pollut. 2008, 192, 349-359. [CrossRef]

41. Bowman, R.S.; Haggerty, G.M.; Huddleston, R.G.; Neel, D.; Flynn, M.M. Chapter 5: Sorption of nonpolar organic compounds, inorganic cations, and inorganic oxyanions by surfactant-modified zeolites. In Surfactant-Enhanced Subsurface Remediation: Emerging Technologies; ACS Symposium Series 594; Sabatini, D.A., Knox, R.C., Harwell, J.H., Eds.; American Chemical Society: Washington, DC, USA, 1995; pp. 54-64.

42. Ahn, C.; Mitsch, W.J.; Wolfe, W.E. Effects of recycled FGD liner materail on water quality and macrophytes of constructed wetlands: A Mesocosm experiment. Water Res. 2001, 35, 633-642. [CrossRef]

43. Lee, T.; Benson, C.H. Sorption and degradation of alachlor and metochlor in ground water using green sands. J. Environ. Qual. 2004, 33, 1682-1693. [CrossRef] [PubMed]

44. Jeong, Y.; Fan, M.; Singh, S.; Chuang, C.-L.; Saha, B.; van Leeuwen, J.H. Evaluation of iron oxide and aluminum oxide as potential arsenic(V) adsorbents. Chem. Eng. Process. 2007, 46, 1030-1039. [CrossRef]

45. Gupta, V.K.; Gupta, B.; Rastogi, A.; Agarwal, S.; Nayak, A. Pesticides removal from waste water by activated carbon prepared from waste rubber tire. Water Res. 2011, 45, 4047-4055. [CrossRef] [PubMed]

46. Hornbuckle, J.W.; Christen, E.W.; Faulkner, R.D. Evaluating a multi-level subsurface drainage for improved drainage water quality. Agric. Water Manag. 2007, 89, 208-216. [CrossRef]

47. Wichelns, D.; Cone, D.; Stuhr, G. Evaluating the impact of irrigation and drainage policies on agricultural sustainability. Irrig. Drain. Syst. 2002, 16,1-14. [CrossRef]

48. Smedema, L.K.; Vlotman, W.F.; Rycroft, D.W. Modern Land Drainage: Planning, Design and Management of Agricultural Drainage Systems; A.A. Balkema Publishers: Leiden, The Netherlands, 2004; pp. 231-255.

49. Henschke, C.; Hermann, T. Testing for Soil and Water Salinity; Fact Sheet 66/00; Government of South Australia-Primary Industries and Resources SA: Adelaide, Australia, 2007; pp. 1-4.

50. Satapanajaru, T.; Comfort, S.D.; Shea, P.J. Enhancing metolachlor destruction rates with aluminum and iron salts during zerovalent iron treatment. J. Environ. Qual. 2003, 32, 1726-1734. [CrossRef] [PubMed]

51. Cheng, S.F.; Huang, C.Y.; Liu, J.Y. Study of different methods for enhancing the nitrate removal efficiency of a zero-valent metal process. Water Sci. Technol. 2006, 53, 81-87. [CrossRef]

52. Lee, S.; Lee, K.; Rhee, S.; Park, J. Development of a new zero-valent iron zeolite material to reduce nitrate without ammonium release. J. Environ. Eng. 2007, 133, 6-12. [CrossRef]

53. Ahn, S.C.; Oh, S.; Cha, D.K. Enhanced reduction of nitrate by zero-valent iron at elevated temperatures. J. Hazard. Mater. 2008, 156, 17-22. [CrossRef] [PubMed]

54. Parsons, T.R.; Maita, Y.; Lalli, C.M. A Manual of Chemical and Biological Methods for Seawater Analysis; Pergamon Press: Oxford, UK, 1984; pp. 1-173.

55. Herzog, D.R. Immunoassays for Environmental Contaminants: (Pesticides) in Food and Water; Technical Bulletin T00037; Strategic Diagnostics Inc.: Newark, NJ, USA, 1997; pp. 1-26.

56. Munch, J.W. Method 525.2: Determination of organic compounds in drinking water by liquid-solid extraction and capillary column gas chromatography/mass spectrometry. In Methods for the Determination of Organic Compounds in Drinking Water; Publication-EPA/600/R-95/131; U.S. Environmental Protection Agency: Washington, DC, USA, 1995; pp. 525.2.1-525.2.60.

57. Rivera-Utrilla, J.; Sanchez-Polo, M. The role of dispersive and electrostaticinteractions in the aqueous phase adsorption of naphthalenesulphonic acids on ozone-treated activated carbons. Carbon 2002, 40, 2685-2691. [CrossRef]

58. Tsang, D.C.W.; Hu, J.; Liu, M.Y.; Zhang, W.; Lai, K.C.K.; Lo, I.M.C. Activated carbon produced from waste wood pallets: Adsorption of three classes of dyes. Water Air Soil Pollut. 2007, 184, 141-155. [CrossRef]

59. Allred, B.J. Laboratory batch test evaluation of effectiveness and efficiency for five filter materials potentially used to remove nutrients and pesticides from subsurface drainage waters. Trans. ASABE 2010, 53, 39-54. [CrossRef]

60. Allred, B.J.; Racharaks, R. Laboratory comparison of four iron-based filter materials for drainage water phosphate treatment. Water Environ. Res. 2014, 86, 852-862. [CrossRef] [PubMed] 
61. Allred, B.J.; Racharaks, R. Preliminary laboratory evaluation of iron-bearing reactive media for pesticide water treatment. Appl. Eng. Agric. 2014, 30, 859-867.

62. Allred, B.J.; Martinez, L.R.; Gamble, D.L. Phosphate removal from agricultural drainage water using an iron oxyhydroxide filter material. Water Air Soil Pollut. 2017, 228, 240. Available online: https://doi.org/10.1007/ s11270-017-3410-9 (accessed on 8 June 2017).

(c)

(C) 2017 by the author. Licensee MDPI, Basel, Switzerland. This article is an open access article distributed under the terms and conditions of the Creative Commons Attribution (CC BY) license (http://creativecommons.org/licenses/by/4.0/). 